\title{
Impatiens wuyiensis (Balsaminaceae), a new species from Fujian of Southeast China, based on morphological and molecular evidences
}

\author{
Jian-Sheng Wang ${ }^{1}$, Yi-Fei Lu², Yue-Liang $\mathrm{Xu}^{3}$, Shui-Hu Jin ${ }^{{ }^{*}}$ and Xiao-Feng Jin ${ }^{4^{*}}$
}

\begin{abstract}
Background: Southeast Asia, together with tropical Africa, Madagascar, South India and Sri Lanka, and the eastern Himalayas, are the five primary hotspots of species diversity of Impatiens (Balsaminaceae). China is also rich in Impatiens species, especially in the limestone karsts or 'Danxia' landforms. With zygomorphic flowers and diverse corolla morphology and color, the species in Impatiens are well-known for their ornamental use, but they are also notorious in taxonomy. During the preparation of revision of Impatiens in Zhejiang and adjacent regions, an unknown species was collected from Mt. Wuyi in Fujian Province, Southeast China.
\end{abstract}

Results: Phylogenetic analyses based on nuclear ITS, chloroplast atpB-rbcL and trnL-F sequences, together with micromorphology of pollen grains and seed coats, strongly supported the close relationship of the new species with Impatiens platysepala Y.L.Chen and I. chloroxantha Y.L.Chen. In turn, both molecular data and morphological characters also were sufficient to distinguish the new species from the other two counterparts.

Conclusions: Our detailed morphological observations and molecular phylogenetic analyses support the recognition of Impatiens wuyiensis as a species new to science.

Keywords: Danxia landform, Flora of Southeast China, Impatiens wuyiensis, Sect. impatiens, Taxonomy

\section{Background}

Impatiens L., containing more than 1000 species, is one of the largest genera of seed plants and is a notorious genus for taxonomic difficulty (Hooker 1908; Chen 1978; Yu et al. 2016). The genus Impatiens has zygomorphic flowers with great diversity both in corolla color and morphology, thus it was regarded as 'the dicot counterpart of the orchid' (Yuan et al. 2004; Yu et al. 2016). Some species, e.g. Impatiens balsamina L. ('balsam') and I. walleriana Hook.f. ('busy lizzie'), are well-known for horticultural value and widely cultivated in East to South

\footnotetext{
*Correspondence: jsh501@163.com; docxfin@163.com

${ }^{1}$ School of Forestry and Bio-Technology, Zhejiang Agricultural and Forestry University, Lin'an 311300, Hangzhou, China

${ }^{4}$ Zhejiang Provincial Key Laboratory for Genetic Improvement and Quality Control of Medicinal Plants \& College of Life and Environment

Sciences, Hangzhou Normal University, Hangzhou 311121, China

Full list of author information is available at the end of the article
}

China. The genus Impatiens differs from its sister group Hydrocera Blume ex Wight \& Arn., a monotypic genus, in having lateral petals (sometimes also called wings) united in pairs and valvate and explosive capsules (Chen 2001; Chen et al. 2007). With membranous dried flowers and easily dehiscent fruits on specimens, descriptions of floral and fruit characters on herbarium specimens may therefore be incomplete or ambiguous. Consequently, field investigations are essential for accurately describing the reproductive characters (Chen 1978; Yu 2012).

The genus Impatiens has five recognized diversity hotspots: viz. tropical Africa, Madagascar, South India and Sri Lanka, the eastern Himalayas, and Southeast Asia (Song et al. 2003; Yuan et al. 2004). China is also rich in Impatiens species, including over 250 species which are mainly distributed in south-western regions, especially in Yunnan, Sichuan, Guangxi, Tibet and Guizhou (Chen 1978; Chen et al. 2007; Shui et al. 2011). Recently, 
molecular phylogenetics has contributed greatly to the understanding of relationships within Impatiens (Yuan et al., 2004; Janssens et al. 2006, 2007, 2012; Yu et al. 2016). Moreover, micromorphology of pollen grains and seed coats of Impatiens have great taxonomic values (Lu 1991; Lu and Chen 1991; Song et al. 2005; Janssens et al. 2012; Cai et al. 2013), and systematic implications (Jin et al. 2008; Guo et al. 2016; Zeng et al. 2016).

Chen $(1988,1989,1999)$ carried out the taxonomic studies and described eight new species from Zhejiang, Anhui and Jiangxi provinces. However, the previous collection of this area was not satisfactory till now. Our field surveys of Impatiens from Zhejiang and adjacent regions in East China have resulted in the discovery of several new species and some infraspecific taxa (Impatiens taishunensis, Chen and Xu 1993; I. jiulongshanica, I. neglacta, I. suichangensis and I. tienmushanica var. longicalculata, Xu and Chen 1999; I. huangyanensis, Jin and Ding 2002; I platysepala var. kuocangshanica, Jin and Zhang 2003; I. yilingiana and I. huangyanensis subsp. attenuata, Jin et al. 2008; I. chekiangensis var. multiflora and var. cangnanensis, $\mathrm{Xu}$ et al. 2018). In this study we report an additional distinctive new species, I. wuyiensis, from one of the typical Danxia landforms in northern Fujian Province, China.

Danxia, literally meaning 'rosy cloud', is a type of sandstone landform found in southeastern, southwestern and northwestern China that consist of a red bedrock characterized by steep cliffs, isolated peaks, steep pillars, ravines, mountains and hills that have formed after a long period of erosion by wind and running water (Liu et al. 1999; Peng et al. 2018). The Danxia landform in Fujian and Guangdong Provinces of China shows the block mountains and looks like isolated islands (Peng et al. 2018).

Based on its flower structure, and micromorphology of pollen grains and seeds, Impatiens wuyiensis is similar to I. platysepala and I. chloroxantha, but evidences of molecular data (ITS, trnL-F and $a t p \mathrm{~B}-r b c \mathrm{~L}$ ) and other morphological characters well support the status of this taxon as new.

\section{Methods}

\section{SEM observations on pollens and seeds}

Dried mature pollen grains and seeds of the new species, together with its allied Impatiens platysepala and I. chloroxantha, were directly collected from the field (see further methodological details in Appendix 1). Pollen grains and seeds were mounted on stubs using doublesided adhesive tape, and directly coated with a layer of gold. The coated pollen grains and seeds were observed and photographed under a Hitachi SU8010 SEM. The sizes of pollen grains and seeds were respectively measured on twenty grains per species using light microscopy. Pollen terminology follows Wang and Wang (1983) and $\mathrm{Lu}$ (1991), and that of seed follows Liu et al. (2004) and Lu and Chen (1991).

\section{Taxon sampling and DNA sequencing}

Seventeen samples representing eight species and one variety of Impateins were collected, and total genomic DNA of these samples were isolated from dried leaf tissue using the TIANGEN Plant Genomic DNA Kit (China). Three DNA regions, ITS (White et al. 1990), $a t p \mathrm{~B}-r b c \mathrm{~L}$ (Janssens et al. 2006), and trnL-F (Taberlet et al. 1991) were amplified. PCR (the polymerase chain reaction) mixture $(25 \mu \mathrm{L})$ contained $12.5 \mu \mathrm{L} 2 \times$ Reaction Mix, $1.0 \mu \mathrm{L}$ each primer $(10 \mathrm{pmol} / \mu \mathrm{L}), 1.0 \mu \mathrm{L}$ genomic DNA $(<0.5 \mu \mathrm{g}), 0.5 \mu \mathrm{L}$ Golden DNA Polymerase $(2.5 \mathrm{U} /$ $\mu \mathrm{L})$ and $9.2 \mu \mathrm{L} d d \mathrm{H} 2 \mathrm{O}$. The PCR conditions were: 1 cycle of $3 \mathrm{~min}$ at $94{ }^{\circ} \mathrm{C}$ for denaturation, 35 cycles of $30 \mathrm{~s}$ at $94{ }^{\circ} \mathrm{C}$ for denaturation (for ITS, 38 cycles), $30 \mathrm{~s}$ at $55{ }^{\circ} \mathrm{C}$ for annealing and $1 \mathrm{~min}$ at $72{ }^{\circ} \mathrm{C}$ for extension (for ITS, $45 \mathrm{~s}$ ), with a final $5 \mathrm{~min}$ extension at $72^{\circ} \mathrm{C}$. The successful PCR products were checked using a $1 \%$ agarose gel electrophoresis. Sequencing was carried out on an ABI 3730 automated sequencer (Applied Biosystems, USA).

A total of 116 sequences representing 34 taxa (Impatiens species and varieties, plus Hydrocera triflora as outgroup) were used to test the phylogenetic placement of the new species. The sampling representatively covered all the sections (with the exception of sect. Tuberosae) known in the phylogeny of Impatiens (Yu et al. 2016). Fifty-one sequences representing nine taxa being collected in the field were newly generated in this study. The rest of the sequences were obtained from GenBank (Appendix 1).

\section{Phylogenetic analysis}

Sequences were assembled and edited using DNAStar Lasergene 7.1 software. Assembled sequences of the same locus were aligned using MAFFT online version (https:// mafft.cbrc.jp/alignment/server/) and trimmed manually in Mega 7.0 (Kumar et al. 2016). The best-fit nucleotide 
substitution models were determined by the Akaike Information Criterion (AIC) using JmodelTest 2 (Darriba et al. 2012), which resulted in ITS for GTR $+I+G$,

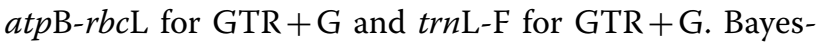
ian Inference (BI) was conducted in MrBayes 3.2.6 (Ronquist and Huelsenbeck 2003), running for 10 million generations and sampling one tree every 1000 generations with four chains of Markov chain Monte Carlo (MCMC). A 50\% majority-rule consensus tree was calculated after discarding the first $25 \%$ trees as burn-in. A Maximum parsimony (MP) analysis was conducted using PAUP v.4.0b10 (Swofford 2003), using a heuristic search algorithm with 1000 random addition replicates and tree bisection-reconnection (TBR) branch-swapping. Node support was assessed using 1000 MP bootstrap (BS) replicates.

\section{Results and discussion}

Micromorphology of the pollen grains of the new species, Impatiens platysepala and I. chloroxantha were shown in Fig. 1. All were oblong-ellipsoid, regularly reticulate, densely granulate in lumen, and with a few perforations. The size of the pollen grains of the new species $(\mathrm{E} 1 \times \mathrm{E} 2)$ was $35.20( \pm 1.01) \times 16.27( \pm 1.00) \mu \mathrm{m}$, and those of $I$. platysepala and $I$. chloroxantha were respectively 35.27 $( \pm 1.30) \times 16.98( \pm 1.21) \mu \mathrm{m}$ and $34.08( \pm 1.82) \times 16.40$ $( \pm 1.26) \mu \mathrm{m}$. This confirmed that the size and micromorphology of pollen grains is similar among three species (Fig. 1).

Seeds of the new species, Impatiens platysepala and I. chloroxantha were all ovoid, slightly compressed, and surface cells regularly elevated, with granules on cell surfaces. The micromorphology of seed coat was revealed to be closely similar in the three studied species (Fig. 2). The seed size of the new species (length $\times$ width) was 2.39 $( \pm 0.12) \times 1.29( \pm 0.12) \mathrm{mm}$, and those of I. platysepala and $I$. chloroxantha were respectively $2.51( \pm 0.10) \times 1.54$ $( \pm 0.11) \mathrm{mm}$ and $2.96( \pm 0.20) \times 1.63( \pm 0.16)$. Observed seed size of $I$. chloroxantha was larger than in I. platysepala and the new species (Fig. 2).

The combined dataset of ITS, atpB-rbcL and $\operatorname{trn} \mathrm{L}-\mathrm{F}$ included 2505 aligned characters (ITS: $697 \mathrm{bps}$, atpB$r b c \mathrm{~L}: 869$ bps and trnL-F: $939 \mathrm{bps})$. The phylogram with posterior probability values (PP) of Bayesian analysis and bootstrap supports (BS) of Maximum parsimony analysis is respectively depicted in Fig. 3. Five individuals of the new species were shown forming a well-supported clade $(\mathrm{PP}=1.00$, and $\mathrm{BS}=99)$, which was sister to the clade of two similar species, I. platysepala and I. chloroxantha. Together with the other ten speices (I. chekiangensis, I. noli-tangere, I. tienmushanica, I. davidi etc.), these species are easily distiguished as members in I. sect. Impatiens, which is characterized by inflorescence shortly racemose or umbel-like, ovary 5-capellate, and capsules clavate (Yu et al. 2016).

\section{Conclusion}

According to our results, we proceed to formally describe the new species.

Impatiens wuyiensis J.S.Wang, Y.F.Lu \& X.F.Jin, sp. nov.: TYPE: CHINA, Fujian, Wuyishan City, Mt. Wuyi, Dawangfeng, moist places by roadside, $27^{\circ} 38^{\prime} 57.13^{\prime \prime} \mathrm{N}$, $117^{\circ} 57^{\prime} 47.42^{\prime \prime} \mathrm{E}$, alt. $420 \mathrm{~m}, 23$ May 2018, X.F. Jin, Y.F. Lu EJ.S. Wang 4158 (holotype: ZM barcode ZMNH0068001, isotypes: HTC barcode HTC0021906, KUN, PE, ZJFC). 武夷凤仙花 (Figs. 4 and 5).

Diagnosis: Haec species in characteribus floralibus est affinis Impatienti platysepalae Y.L. Chen et I. chloroxanthae Y.L. Chen, a qua floribus luteis, sepalis lateralibus dense purpureo-rubro-maculatis, costas vexilli dorso in medio breviter clavatis vel cornutis, bracteis herbaceis linearis vel anguste ovato-lanceolatis, 3-4 $\mathrm{mm}$ longis, ca. $0.5 \mathrm{~mm}$ latis differt.

Description: Herbs annual, $20-75 \mathrm{~cm}$ tall, glabrous. Stems succulent, erect, usually simplex; lower nodes swollen or slightly swollen. Leaves alternate; blades membranous, ovate-elliptic or elliptic-oblong, rarely ovate or oblong, $2.5-13 \mathrm{~cm}$ long, $1.5-5.5 \mathrm{~cm}$ wide, apex acuminate, base cuneate and gradually attenuate into a 1-8 cm long petiole (upper aggregated leaves subsessile), margin crenate and mucronulate, dark green adaxially, pale green and pale red abaxially, lateral veins $6-8$ pairs, obliquely curved. Inflorescence in leaf axils, shortly racemose or umbel-like, shorter than leaves; peduncles shorter than petioles, 10-13 mm long, 2-4-flowered, rarely 5- or 6-flowered; pedicels $14-20 \mathrm{~mm}$ long, base bracteate; bracts herbaceous, persistent, linear or narrowly ovate-lanceolate, $3-4 \mathrm{~mm}$ long, ca. $0.5 \mathrm{~mm}$ wide, apex acuminate. Flowers golden yellow, $4-5 \mathrm{~cm}$ long, $2-2.2 \mathrm{~cm}$ wide. Lateral sepals 2 , broadly ovate or ovaterounded, 6-7 $\mathrm{mm}$ long, 5.5-6.5 $\mathrm{mm}$ wide, densely purple-red spotted, base nearly aequlilateral, apex obtuse 


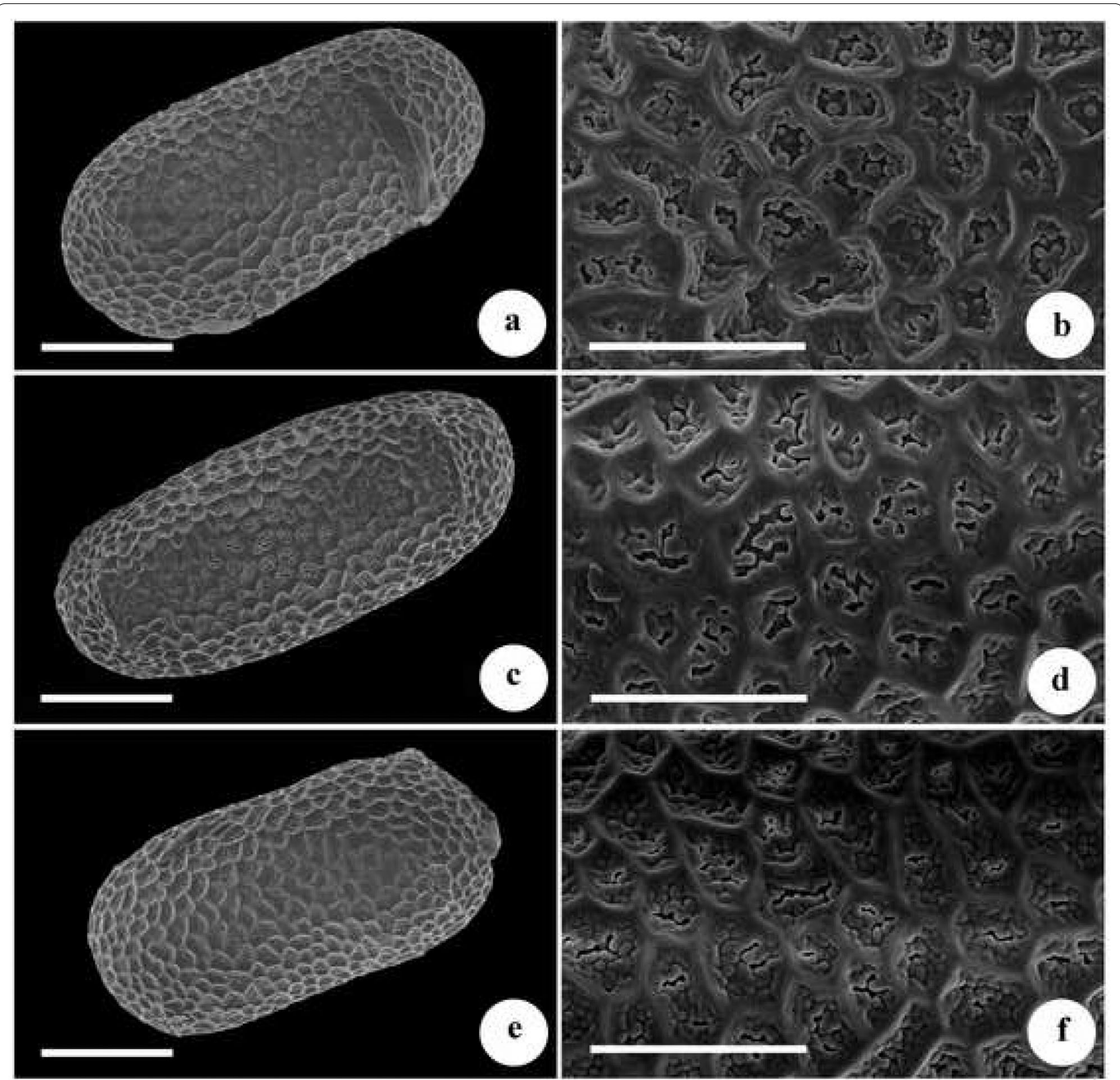

Fig. 1 Micromorphology of pollen grains of Impatiens wuyiensis, I. platysepala and I. chloroxantha. a, b I. wuyiensis; c, d I. platysepala; e, f I. chloroxantha. a, c, e overview of pollen grain (scale bar: $10 \mu \mathrm{m}$ ); b, d, $\mathbf{f}$ sexine sculpture (scale bar: $5 \mu \mathrm{m}$ ) 


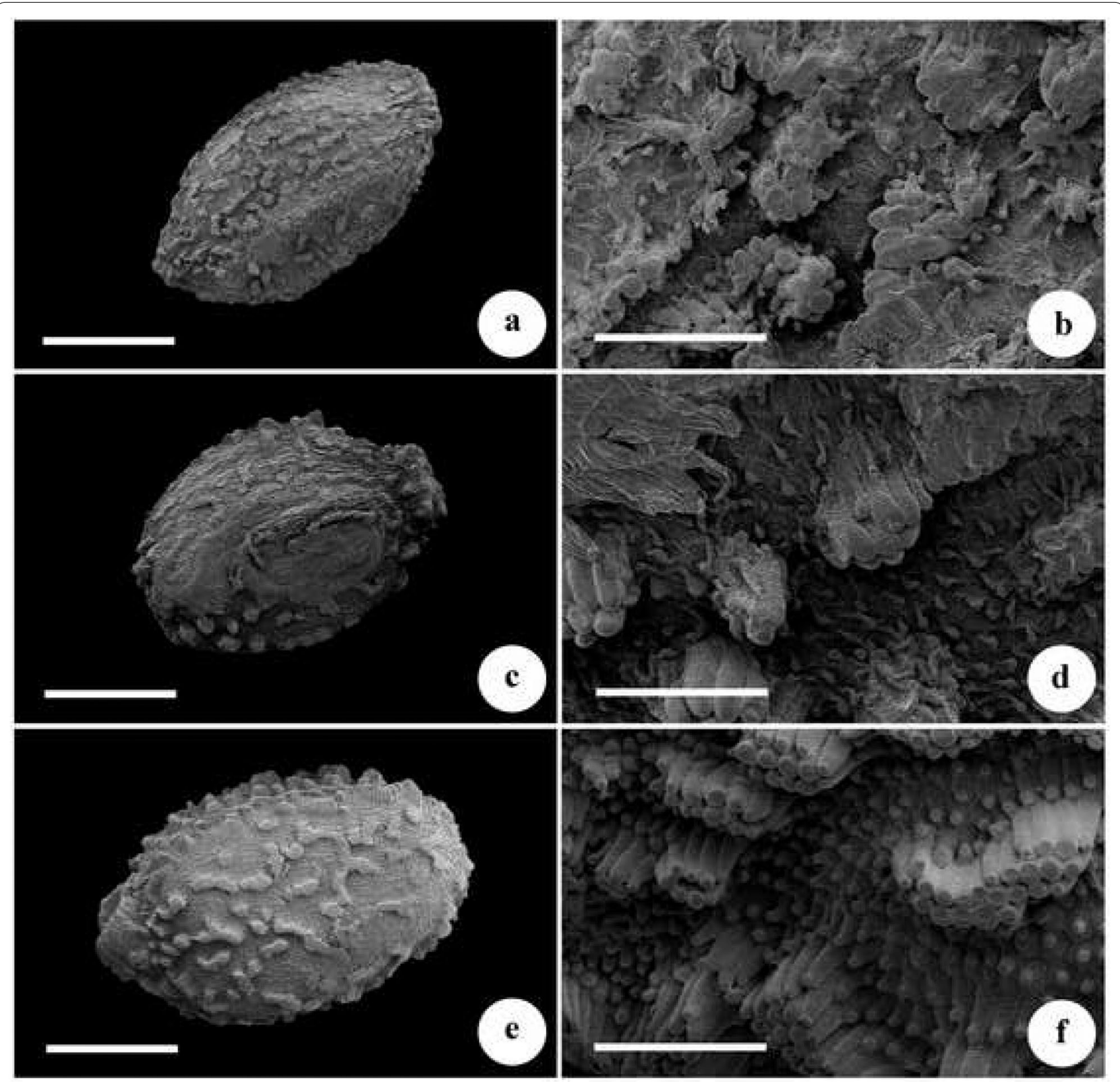

Fig. 2 Micromorphology of seeds of Impatiens wuyiensis, I. platysepala and I. chloroxantha. a, b I. wuyiensis; c, d I. platysepala; e, f I. chloroxantha. a, c, e shape of seeds (scale bar: $1 \mathrm{~mm}$ ); $\mathbf{b}, \mathbf{d}, \mathbf{f}$ surface ornamentation of seedcoat (scale bar: $200 \mu \mathrm{m}$ ) 


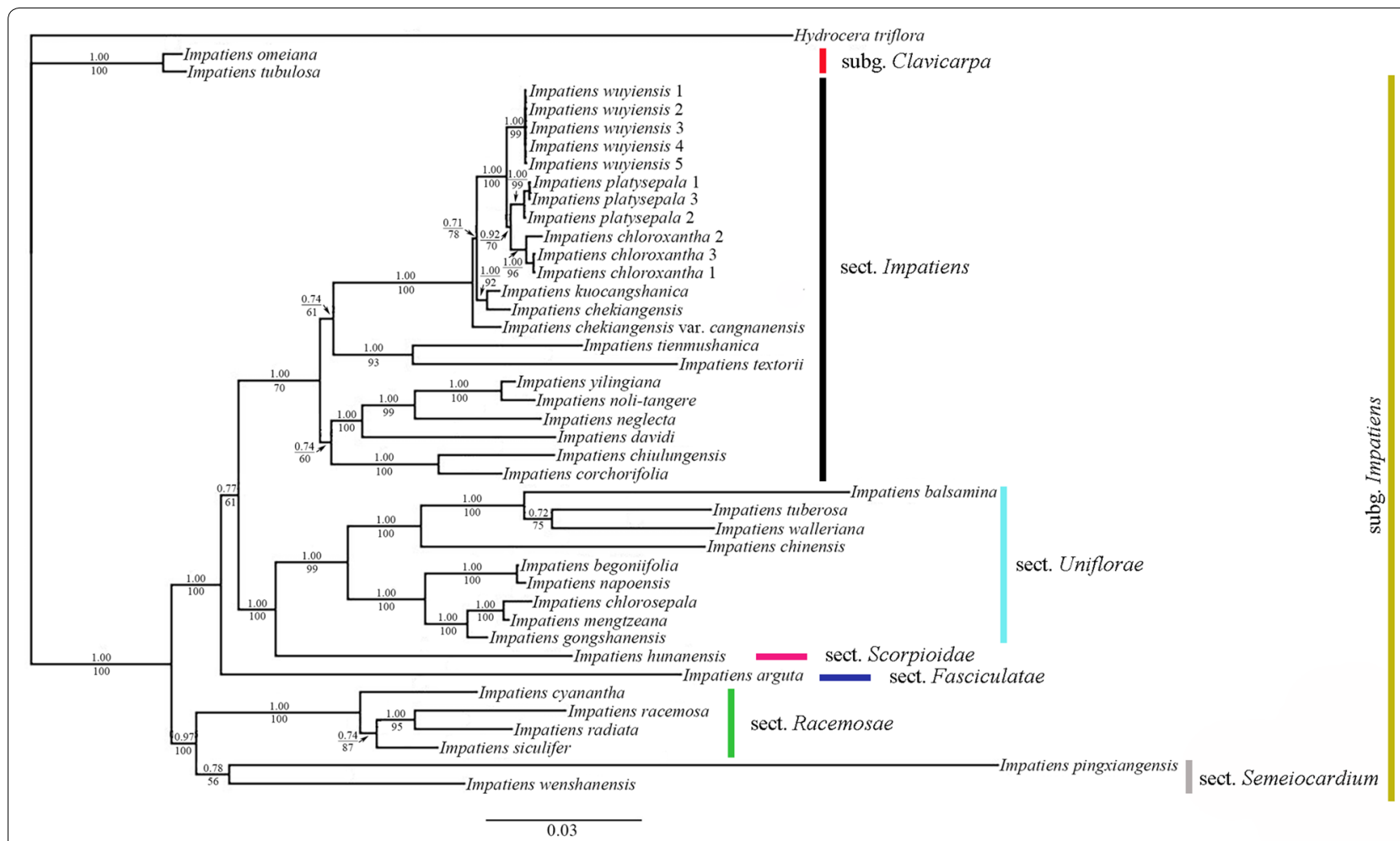

Fig. 3 Majority consensus tree inferred from Bayesian analysis based on the nrDNA ITS and cpDNA atpB-rbcL and trnL-F data. Values above the branches are Bayesian posterior probabilities (PP $\geq 50 \%$ ), and those below the branches are maximum parsimony bootstrap supports (BS $\geq 50 \%)$

and mucronulate, abaxial midvein keeled. Lower sepal funnelform, 4-4.5 cm long, purple-red striate, base abruptly narrowed into a $2.5-3 \mathrm{~cm}$ long and slightly incurved spur; mouth vertical, $16-18 \mathrm{~mm}$ wide, tip acute. Upper petal orbicular, 11-13 mm long, 19-21 mm wide, purple-red spotted, apex emarginate and mucronate, abaxial midvein keeled and clavate or corned at middle.
Lateral united petals $22-25 \mathrm{~mm}$ long, $12-14 \mathrm{~mm}$ wide, purple-red striate, 2-lobed; basal lobes oblong, 8-9 mm long, 3-3.5 mm wide, apex obtuse, with a $4-4.5 \mathrm{~mm}$ long stipe; distal lobes dolabriform, apex obtuse, with reflexed and golden yellow auricle. Stamens 5; filaments 4-6 mm long; anthers ovoid, apex obtuse. Ovary fusiform, ca. 


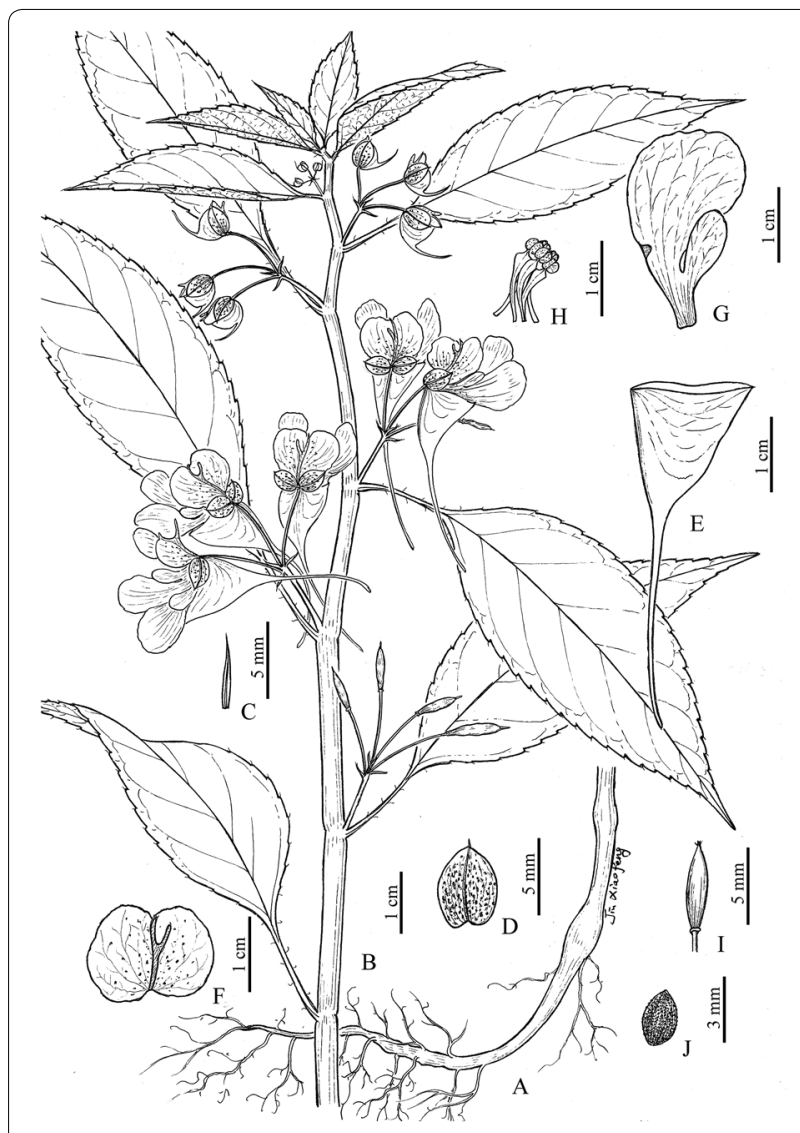

Fig. 4 Impatiens wuyiensis J.S.Wang, Y.F.Lu \& X.F.Jin. a habit (showing lower part and roots); $\mathbf{b}$ habit (showing upper part); $\mathbf{c}$ bract; $\mathbf{d}$ lateral sepal; e lower sepal; f upper petal; $\mathbf{g}$ lateral petals; $\mathbf{h}$ stamens; i ovary; j seed (Drawn by X.F. Jin from the holotype)

$3 \mathrm{~mm}$ long, apex acute. Capsule clavate, 10-20 mm long, apex with a $2-3.5 \mathrm{~mm}$ long beak. Seeds ovoid, brown, ca. $2.5 \mathrm{~mm}$ long, ca. $2 \mathrm{~mm}$ wide, densely verrucous.
Distribution, habitat and ecology: Impatiens wuyiensis seems to be restricted to Mt. Wuyi. It is widely distributed along several scenic spots, such as Dawangfeng, Tianyoufeng, Shuiliandong and Lianhuafeng views. It grows in moist places by roadside or in grasslands, on rock face, under forest or at forest margins, at an elevation between 220 and $430 \mathrm{~m}$ (Fig. 5: a, b).

Phenology: Flowering and fruiting of this new species is from early April to late September.

Etymology: The specific epithet 'wuyiensis' is derived from the type locality, Mt. Wuyi, northern Fujian Province.

Notes: This new species is morphologically similar to Impatiens platysepala and I. chloroxantha in habit and floral structure (Chen 1988, 2001; Zhang et al. 2017), but is easily distinguished from these two species in having flowers golden yellow, lateral sepals densely purplered spotted, upper petals with abaxial midvein clavate or corned at midle, bracts herbaceous, linear or narrowly ovate-lanceolate, $3-4 \mathrm{~mm}$ long, ca. $0.5 \mathrm{~mm}$ wide. Morphological characters distinguishing the new species from Impatiens platysepala and I. chloroxantha are detailed in Table 1, Figs. 5 and 6.

Micromorphology of pollen grains and seeds of the new species, Impatiens platysepala and I. chloroxantha revealed that these three species are closely related. Phylogenetic analysis detected that the new species is also related to I. platysepala and I. chloroxantha, but considerably different from each another with strong supports.

Additional specimens examined (paratypes): Fujian, Wuyishan City, Mt. Wuyi, Dawangfeng, moist places by roadside, $27^{\circ} 38^{\prime} 57.15^{\prime \prime} \mathrm{N}, 117^{\circ} 57^{\prime} 47.36^{\prime \prime} \mathrm{E}$, alt. $430 \mathrm{~m}, 23$ May 2018, X.F. Jin, Y.F. Lu E J.S. Wang 4156 (ZJFC, ZM), ibid., 23 May 2018, X.F. Jin, Y.F. Lu \& J.S. Wang 4157 (PE, ZJFC, ZM); Mt. Wuyi, Shuiliandong, in grass under forest, $27^{\circ} 40^{\prime} 56.23^{\prime \prime} \mathrm{N}, 117^{\circ} 58^{\prime} 32.04^{\prime \prime} \mathrm{E}$, alt. $220 \mathrm{~m}$, X.F. Jin, Y.F. Lu E J.S. Wang 4165 (ZM), 4166 (KUN, PE, ZM), 4167 (KUN, PE, ZM), ibid., by stream, alt. 270 m, 4 April 

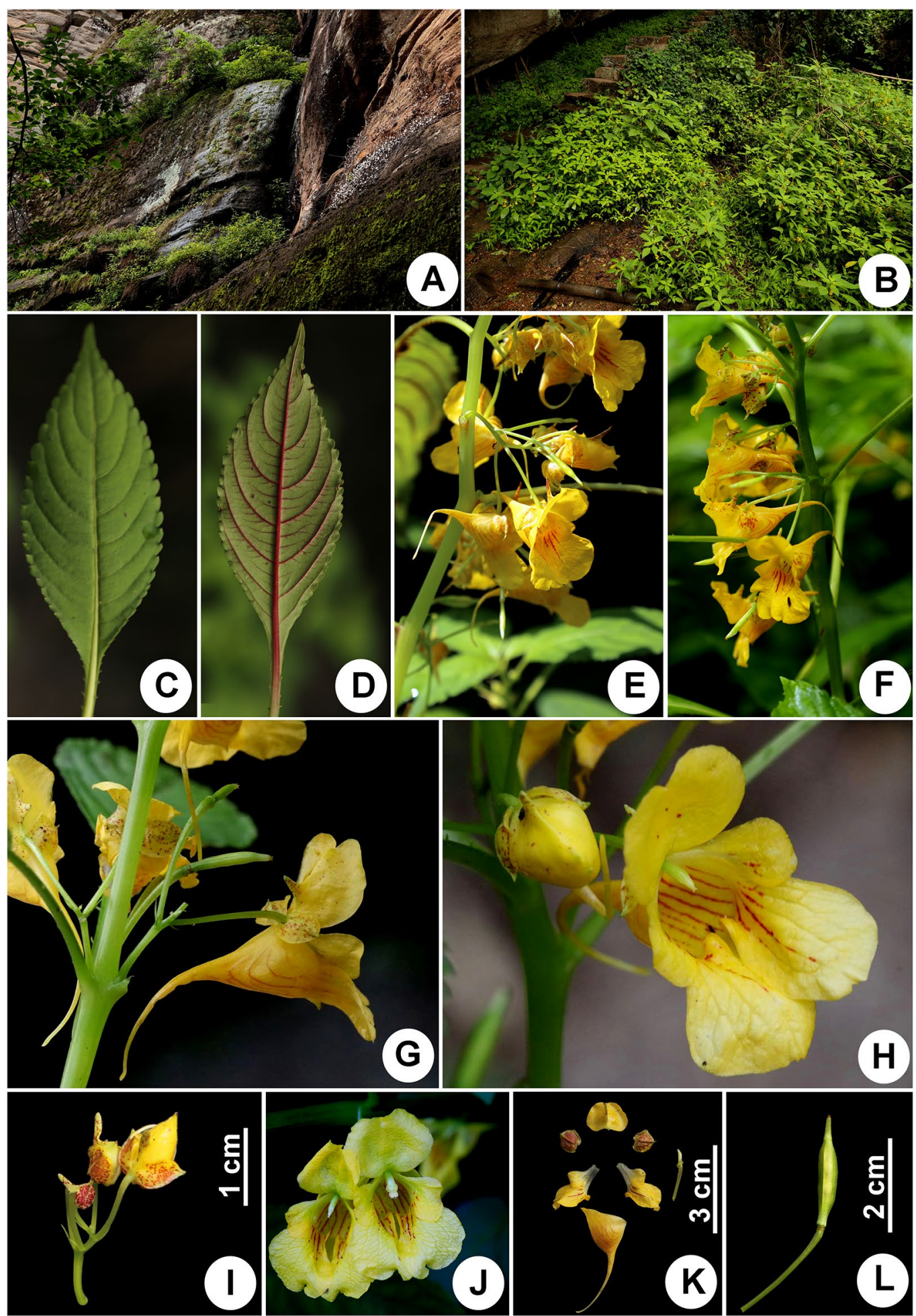

Fig. 5 Impatiens wuyiensis J.S.Wang, Y.F.Lu \& X.F.Jin. a, b habitat; c adaxial surface of leaf; $\mathbf{d}$ abaxial surface of leaf; $\mathbf{e}, \mathbf{f}$ inflorescence; $\mathbf{g}$ lateral view of flower; $\boldsymbol{h}$ frontal view of flower; i pedicel and bract; $\mathbf{j}$ upper petal and lateral united petals; $\mathbf{k}$ flower structure; $\mathbf{I}$ capsule 
Table 1 Comparison of Impatiens wuyiensis, I. platysepala and I. Chloroxantha

\begin{tabular}{|c|c|c|c|}
\hline Characters & Impatiens wuyiensis & Impatiens platysepala & Impatiens chloroxantha \\
\hline \multicolumn{4}{|l|}{ Leaves } \\
\hline Abaxial color & Pale green and pale red & Pale green, rarely pale red & Pale green \\
\hline Lateral veins & 6-8 pairs & 8-11 pairs & 7-9 pairs \\
\hline \multicolumn{4}{|l|}{ Bracts } \\
\hline Texture & Herbaceous & Thinly membranous & Thinly membranous \\
\hline Shape & Linear or narrowly ovate-lanceolate & Ovate-lanceolate & Ovate or narrowly ovate \\
\hline Size & $3-4 \times$ ca. $0.5 \mathrm{~mm}$ & $10-12 \times 4-6 \mathrm{~mm}$ & $8-11 \times 4-5 \mathrm{~mm}$ \\
\hline \multicolumn{4}{|l|}{ Flower } \\
\hline Color & Golden yellow & Pink & Yellow-green \\
\hline Lateral sepals & Densely purple-red spotted & Not spotted & Not spotted \\
\hline Upper petals & Middle with abaxial midvein clavate or corned & Middle with abaxial midvein cristate & Middle with abaxial midvein cristate \\
\hline
\end{tabular}

2019, X.F. Jin, Y.F. Lu \& J.S. Wang 4375 (ZJFC, ZM), ibid., 21 September 2019, X.F. Jin \& Y.F. Lu s. n. (ZM); Mt. Wuyi, Tianyoufeng, in grass by roadside, alt. $227 \mathrm{~m}, 7$ May 2019, Y.F. Lu 186 (ZM).

\begin{abstract}
Acknowledgements
The authors are grateful to Prof. Zheng-Hai Chen and Ms. Ju-Lian Liu for collecting some materials, to Mr. Bi-Cheng Hu, Ms. Ling-Xian Chen, Mr. Li-Xin Ye, Mr. Sheng-Long Liu, Mr. Zi-Lin Chen and Mr. Pan Wang for their assistance during the field trips, to Dr. Pedro Jiménez-Mejías for improving the English, and to Prof. Wen-Tsai Wang for modification of Latin diagnosis.
\end{abstract}

\section{Authors' contributions}

JSW, YFL and XFJ discovered the new species, SHJ and XFJ designed the project, JSW, YFL, YLX and XFJ collected the materials, YFL and XFJ collected the molecular data and performed the analysis, JSW, YFL and XFJ wrote the first draft of the manuscript. All authors read and approved the final manuscript.

\section{Funding}

Supported by the National Natural Science Foundation of China (Grant No. 31770212), the provincial project of the new edition of Flora of Zhejiang (Grant No. 335010-2015-0005) and Hangzhou scientific and technological planning project (Grant No. 20170432B06).

\section{Availability of data and materials}

All DNA sequences generated in this study have been registered to GenBank.

Ethics approval and consent to participate

Not applicable.

\section{Consent for publication}

Not applicable.

\section{Competing interests}

The authors declare that they have no competing interests.

\section{Author details}

${ }^{1}$ School of Forestry and Bio-Technology, Zhejiang Agricultural and Forestry University, Lin'an 311300, Hangzhou, China. ${ }^{2}$ College of Life Sciences, Zhejiang University, Hangzhou 310058, China. ${ }^{3}$ Zhejiang Museum of Natural History, Hangzhou 310014, China. ${ }^{4}$ Zhejiang Provincial Key Laboratory for Genetic Improvement and Quality Control of Medicinal Plants \& College of Life and Environment Sciences, Hangzhou Normal University, Hangzhou 311121 China.

\section{Appendix 1}

Taxon: NCBI accession numbers (ITS/atpB-rbcL/trnLF), voucher information. Samples marked with '"' were newly added, and '\#' were those pollen grains and seeds collected.

Hydrocera triflora (L.) Wright \& Arn.: AY348853/ DQ147895/ -, Sri Lanka, Robyns 7260, 0,249,369 (BR).

Impatiens arguta Hook.f. \& Thomson: AY348746/ DQ147812/ KP776116, China, Yunnan and Xizang, Y. M. Yuan CN2k1-74 (NEU) and S.X. Yu 5406 (PE).

I. balsamina L.: AY348749/ DQ147816/ -, Kruidtuin Leuven (Cult.), Janssens SJ 001 (LV).

I. begoniifolia S. Akiyama \& H. Obha: AY348752/ DQ147819/ -, China, Yunnan, Y. M. Yuan CN2k1-51 (NEU).

I. chekiangensis Y.L.Chen: KP776064/ KP776014/ KP776121, China, Zhejiang, H.N. Qin et al. 20,141 (PE).

I. chekiangensis Y.L.Chen var. cangnanensis Y.L.Xu \& X.F.Jin*: MN974564/ MN974547/ MN974581, China, Zhejiang, Cangnan, Dangyuanlin, Y.L Xu 318 (ZM).

I. chinensis L.: AY348761/ DQ147825/ KP776122, China, Yunnan and Guangxi, Y.M. Yuan CN2k149 (NEU) and I. chiulungensis Y.L.Chen: KP776066/ KP776016/ KP776124, China, Sichuan, S.X. Yu et al. 3989 (PE).

I. chlorosepala Hand.-Mazz.: KP776067/ KP776017/ -, China, Guangxi, S.X. Yu et al. 4209 (PE).

I. chloroxantha Y.L.Chen (individual 1)": MN974563/ MN974546/ MN974580, China, Zhejiang, Suichang, Mt. Jiulong, Luohanyuan, X.F. Jin s. n. (HTC). I. chloroxantha Y.L.Chen (individual 2)*\#: MN974573/ MN974556/ MN974590, China, Zhejiang, Suichang, Mt. Jiulong, Luohanyuan, J.L. Liu s. n. (HTC). I. chloroxantha Y.L.Chen (individual 3)*: MN974574/ MN974557/ MN974591, 

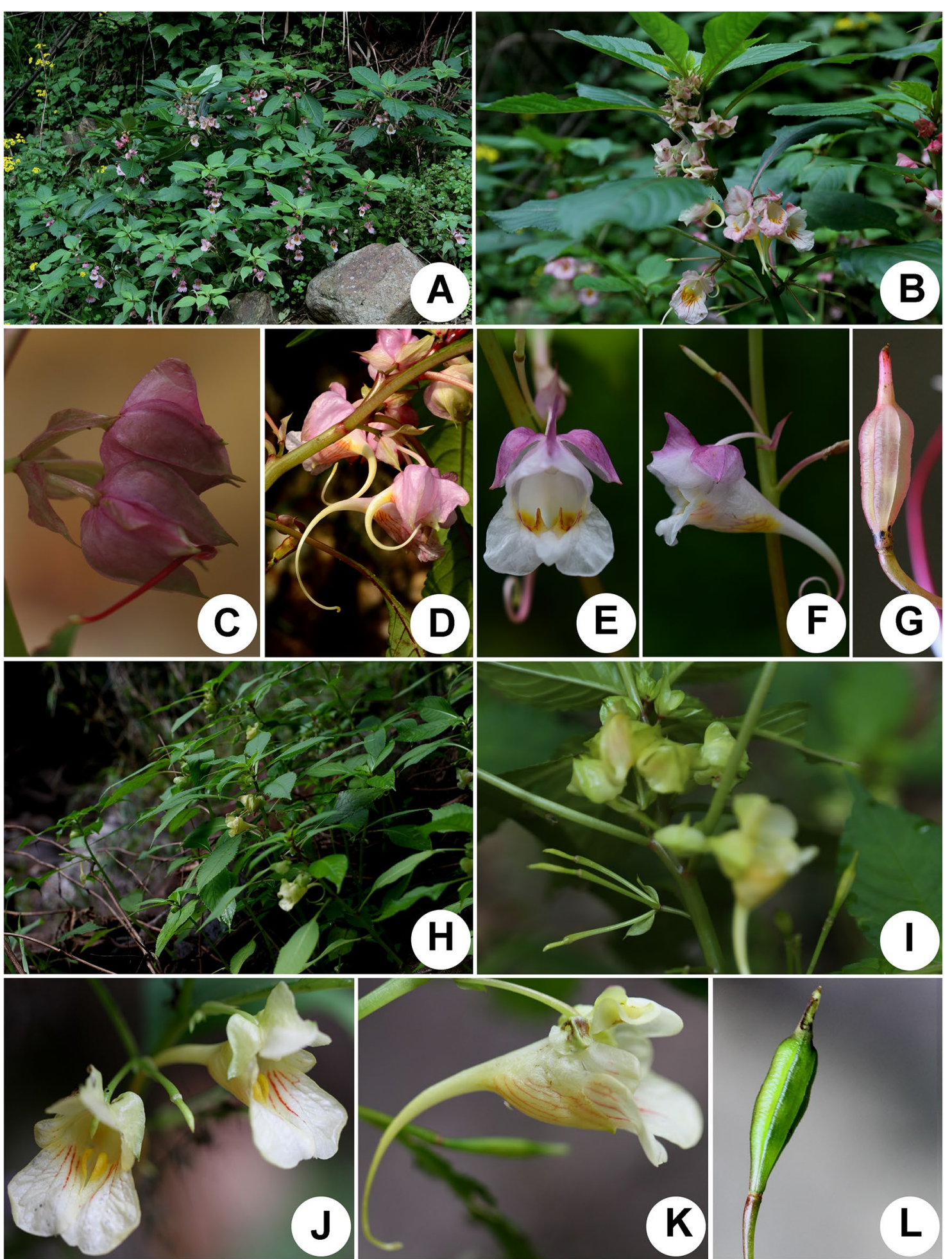

Fig. 6 Impatiens platysepala Y.L.Chen (a-g) and I. chloroxantha Y.L.Chen (h-I). a habitat; b upper part of plant; $\mathbf{c}$ bracts and flowers; $\mathbf{d}$ inflorescence; e frontal view of flower; $\mathbf{f}$ lateral view of flower; $\mathbf{g}$ capsule; $\mathbf{h}$ habitat; $\mathbf{i}$ inflorescence and bracts; $\mathbf{j}$ frontal view of flower; $\mathbf{k}$ lateral view of flower; $\mathbf{I}$ capsule 
China, Zhejiang, Suichang, Mt. Jiulong, Luohanyuan, J.L. Liu s. n. (HTC).

I. corchorifolia Franch.: AY348767/ DQ147831/ KP776127, China, Yunnan and Sichuan, Chassot \& Y.M. Yuan 99-173 (NEU) and S.X. Yu et al. 4596 (PE).

I. cyanatha Hook.f.: AY348770/ DQ147833/ -, China, Yunnan, Y.M. Yuan CN2k1-84 (NEU).

I davidi Franch.": MN974568/ MN974551/ MN974585, China, Zhejiang, Yinzhou, Wulongtan, X.F. Jin \& Y.F. Lu 4357 (HTC).

I. gongshanensis Y.L.Chen: KP776074/ KP776024/ KP776135, Myanmar, Putao, PT-ET 975 (PE).

I. hunanensis Y.L.Chen: KP776077/ KP776028/ KP776137, China, Guangxi, S.X. Yu 3759 (PE).

I. kuocangshanica (X.F.Jin \& F.G.Zhang) X.F.Jin \& Y.L.Xu*: MN974567/ MN974550/ MN974584, China, Zhejiang, Linhai, Mt. Kuocang, Zhangjiadu, B.Y. Ding E X.F. Jin 6924 (PE).

I. mengtzeana Hook.f.: AY348806/ DQ147858/ -, China, Yunnan, Y.M. Yuan CN2k1-60 (NEU).

I. neglecta Y.L.Xu \& Y.L.Chen": MN974569/ MN974552/ MN974586, China, Zhejiang, Longquan, Mt. Fengyang, Y.F. Lu 203 (HTC).

I. napoensis Y.L.Chen: AY348811/ DQ147861/ KP776146, China, Yunnan and Guangxi, Y.M. Yuan CN2k1-61 (NEU) and S.X. Yu 3049 (PE).

I. noli-tangere L.: KP776088/ KP776039/ KP776148, China, Guangxi, S.X. Yu 4017 (PE).

I. omeiana Hook.f.: KP776092/ DQ147864/ KP776152, China, Sichuan and Univ. California Bot. Gard. (Cult.), S.X. Yu 4093 (PE) and 2002.0214 (UC).

I. pingxiangensis H.Y.Bi \& S.X.Yu: KP776093/ KP776043/ -, China, Guangxi, S.X. Yu et al. 3088 (PE).

I. platysepala Y.L.Chen (individual 1)"\#: MN974572/ MN974555/ MN974589, China, Zhejiang, Jiangshan, Zhoucun, Z.H. Chen et al. JS19061201 (HTC). I. platysepala Y.L.Chen (individual 2)*: MN974570/ MN974553/ MN974587, China, Zhejiang, Jiangshan, Zhoucun, Z.H. Chen et al. JS19061203 (HTC). I. platysepala Y.L.Chen (individual 3)*: MN974571/ MN974554/ MN974588, China, Zhejiang, Jiangshan, Nianbadou, Z.H. Chen et al. JS19061205 (HTC).

I. racemosa DC.: KP776098/ DQ147873/ KP776159, China, Yunnan and Xizang, S.X. Yu 4221 (PE) and De Haas 2620 (U).

I. radiata Hook.f.: AY348824/ KP776047/ KP776160, China, Xizang and Sichuan, De Haas 2620 (U) and S.X. $Y u$ et al. 4760 (PE).

I. siculifer Hook.f.: KP776101/ KP776049/ -, China, Guangxi, S.X. Yu 3211 (PE).

I. textori Miq.: AY348841/ -/ KP776168, Japan and Korea, Kanno et al. 1114 (TUS) and H.N. Qin et al. 18,048 (PE).
I. tienmushanica Y.L.Chen": MN974565/ MN974548/ MN974582, China, Zhejiang, Pan'an, Mt. Dapan, Huaxi, Y.F. Lu s. n. (HTC).

I. tuberosa H. Perrier: AY348844/ DQ147886/ -, Madagascan origin: Bot. Gard. Univ. Kopenhagen (Cult.), Janssens SJ 005 (LV).

I. tubulosa Hemsl.: KP776108/ KP776056/ KP776172, China, Guangxi, S.X. Yu 3762 (PE).

I. walleriana Hook.f.: AY348849/ DQ147892/ AB043641, Kenya, Nat. Bot. Gard. Meise (Cult.) and Tokyo (Cult.), O. Phaehler \& M. Schnell I08 (NEU), S3926 (BR) and H. Fujihashi 3 (TI).

I. wenshanensis S.H.Huang: KP776110/ KP776057/ KP776175, China, Guangxi, S.X. Yu 4044 (PE).

I. wuyiensis J.S.Wang, Y.F.Lu \& X.F.Jin (individual 1)*: MN974558/ MN974541/ MN974575, China, Fujian, Mt. Wuyi, Shuiliandong, X.F. Jin et al. 4167 (ZM). I. wuyiensis J.S.Wang, Y.F.Lu \& X.F.Jin (individual 2)*: MN974559/ MN974542/ MN974576, China, Fujian, Mt. Wuyi, Dawangfeng, X.F. Jin et al. 4156 (ZM). I. wuyiensis J.S.Wang, Y.F.Lu \& X.F.Jin (individual 3)*\#: MN974560/ MN974543/ MN974577, China, Fujian, Mt. Wuyi, Dawangfeng, X.F. Jin et al. 4158 (ZM). I. wuyiensis J.S.Wang, Y.F.Lu \& X.F.Jin (individual 4)*: MN974561/ MN974544/ MN974578, China, Fujian, Mt. Wuyi, Shuiliandong, X.F. Jin et al. 4165 (ZM). I. wuyiensis J.S.Wang, Y.F.Lu \& X.F.Jin (individual 5)*: MN974562/ MN974545/ MN974579, China, Fujian, Mt. Wuyi, Tianyoufeng, Y.F. Lu 186 (ZM).

I. yilingiana X.F.Jin, S.Z.Yang \& L.Qian*: MN974566/ MN974549/ MN974583, China, Zhejiang, Lin'an, Mt. Tianmu, Dashuwang, X.F. Jin 1901 (HTC).

Received: 28 January 2020 Accepted: 21 October 2020 Published online: 02 November 2020

References

Cai X-Z, Yi R-Y, Zhuang Y-H, Cong Y-Y, Kuang R-P, Liu K-M (2013) Seed coat micromorphology characteristics of Impatiens $L$. and its systematic significance. Acta Hort Sin 40:1337-1348. https://doi.org/10.16420 /j.issn.0513-353x.2013.07.014

Chen Y-L (1978) Notulae de genere Impatiens L. florae Sinicae. Acta Phytotax $\operatorname{Sin} 16(2): 36-55$

Chen Y-L (1988) A revision of Impatiens L. from Chekiang-studies on the genus Impatiens L. in China (II). Bull Bot Res 8(2):1-15

Chen Y-L (1989) Four new species of Impatiens (Balsaminaceae) from China. Acta Phytotax $\operatorname{Sin}$ 27:395-404

Chen Y-L (1999) Six new species of Impatiens L. from China. Acta Phytotax Sin 37:88-99

Chen Y-L (2001) Flora Reipublicae Popularis Sinicae, Tomus 47(2): Balsaminaceae. Science Press, Beijing

Chen YL, Akiyama S, Ohba H (2007) Balsaminaceae. In: Wu Z-Y, Raven PH (eds) Flora of China, vol 12. Science Press and Missouri Botanical Garden Press, Beijing and St-Louis, pp 43-114

Chen Y-L, Xu Y-L (1993) A new species of Impatiens (Balsaminaceae) from Zhejiang. Bull Bot Res 13(1):11-13 
Darriba D, Taboada GL, Doallo R, Posada D (2012) jModelTest 2: More models, new heuristics and parallel computing. Nature, Meth 9:772

Guo H, Yan R-Y, Zhang M, Luo Q, Zhang L-J, Yu S-X (2016) Taxonomic significance of the pollen morphology of sect. Racemosae (Impatiens). Guihaia 36:83-95. https://doi.org/10.11931/quihaia.gxzw201601175

Hooker JD (1908) Les espèces du genre "Impatiens" dans I'herbier du Museum de Paris. Nouv Arch Mus Nat Hist Paris. Ser. 4, 10: 233-272.

Janssens SB, Geuten K, Yuan Y-M, Song Y, Küpfer P, Smets E (2006) Phylogenetics of Impatiens and Hydrocera (Balsaminaceae) using chloroplast atpB-rbcL spacer sequences. Syst Bot 31:171-180. https://doi. org/10.1600/036364406775971796

Janssens SB, Geuten K, Viaene T, Yuan Y-M, Song Y, Smets E (2007) Phylogenetic utility of the AP3/DEF K-domain and its molecular evolution in Impatiens (Balsaminaceae). Mol Phylogenet Evol 43:255-239. https://doi. org/10.1016/j.ympev.2006.11.016

Janssens SB, Wilson SY, Yuan Y-M, Nagels A, Smets EF, Huysmans S (2012) A total evidence approach using palynological characters to infer the complex evolutionary history of the Asian Impatiens (Balsaminaceae). Taxon 61:355-367. https://doi.org/10.1002/tax.612007

Jin X-F, Ding B-Y (2002) A new species of Impatiens from eastern Zhejiang, China. Acta Phytotax Sin 40:167-169

Jin X-F, Yang S-Z, Chen Z-H, Qian L (2008) Impatiens yilingiana sp. nov. and 1. huangyanensis subsp. attenuata subsp. nov. (Balsaminaceae) from Zhejiang, eastern China. Nordic J Bot 26:207-213. https://doi.org/10.111 1/j.1756-1051.2008.00325.x

Jin X-F, Zhang F-G (2003) A new variety of Impatiens L. from Zhejiang Province. Bull Bot Res 23:141-142

Kumar S, Stecher G, Tamura K (2016) MEGA7: Molecular Evolutionary Genetics Analysis version 7.0 for bigger datasets. Molec Biol Evol 33:1870-1874. https://doi.org/10.1093/molbev/msw054

Liu C-J, Lin Q, He J-X (2004) Methods and terminology of study on seed morphology from China. Acta Bot Bor-Occid Sin 24:178-188

Liu W-Q, Li Z-H, Liu LF (1999) A preliminary study on the flora of the tourist landform of Danxiashan, Guangdong, China. Guihaia 19:15-21

Lu Y-Q (1991) Pollen morphology of Impatiens L. (Balsaminaceae) and its taxonomic implications. Acta Phytotax Sin 29:352-357

Lu Y-Q, Chen Y-L (1991) Seed morphology of Impatiens L. (Balsaminaceae) and its taxonomic implications. Acta Phytotax Sin 29:252-257

Peng H, Liu P, Zhang GH (2018) Small scale vegetation differentiation structure in Danxia landforms. Southeast China. Scientia Geographica Sinica. 38:944-953. https://doi.org/10.13249/j.cnki.sgs.2018.06.014

Ronquist F, Huelsenbeck JP (2003) MrBayes 3: Bayesian phylogenetic inference under mixed models. Bioinformatics 19:1572-1574

Shui Y-M, Janssens S, Huang S-H, Chen W-H, Yang Z-G (2011) Three new species of Impatiens L. from China and Vietnam: preparation of flowers and morphology of pollen and seeds. Syst Bot 36:428-439. https://doi. org/10.1600/036364411X569615

Song Y, Yuan Y-M, Küpfer P (2003) Chromosomal evolution in Balsaminaceae, with cytological observations on 45 species from southeast Asia. Caryologia 56:463-481. https://doi.org/10.1080/00087114.2003.10589359
Song Y, Yuan Y-M, Küpfer P (2005) Seedcoat micromorphology of Impatiens (Balsaminaceae) from China. Bot J Linn Soc 149:195-208. https://doi.org/ 10.1111/j.1095-8339.2005.00436.x

Swofford DL (2003) PAUP*: Phylogenetic Analysis Using Parsimony (*and Other Methods), v4.0b10. Sinauer Associates, Sunderland.

Taberlet P, Gielly L, Pautou G, Bouvet J (1991) Universal primers for amplification of three non-coding regions of chloroplast DNA. Plant Mol Biol 17:1105-1109

Thompson JD, Gibson TJ, Plewniak F, Jeanmougin F, Higgins DG (1997) The ClustalX windows interface: Flexible strategies for multiple sequence alignment aided by quality analysis tools. Nucl Acid Res 25:4876-4882

Wang K-F, Wang X-Z (1983) Outline of Palynology. Peking University Press, Beijing

White TJ, Bruns T, Lee S, Taylor J (1990) Amplification and direct sequencing of fungal ribosomal RNA genes for phylogenetics. In: Innis MA, Gelfand DH, Sninsky JJ, White TJ (eds) PCR Protocols: A Guide to Methods and Applications. Academic Press, New York, pp 315-322

Xu Y-L, Chen Y-L (1999) New taxa of Impatiens L. (Balsaminaceae) from Zhejiang. China Acta Phytotax Sin 37:194-200

Xu Y-L, Zhang H-W, Zhang Y, Zhou X (2018) New materials of seed plants from Zhejiang and Anhui, China. J Hangzhou Univ (Nat Sci Ed) 17:8-10. https:// doi.org/10.3969/j.issn.1674-232X.2018.01.003

Yu S-X (2012) Balsaminaceae of China. Peking University Press, Beijing

Yu S-X, Janssens SB, Zhu X-Y, Lidén M, Gao T-G, Wang W (2016) Phylogeny of Impatiens (Balsaminaceae): integrating molecular and morphological evidence into a new classification. Cladistics 32:179-197. https://doi. org/10.1111/cla.12119

Yuan Y-M, Song Y, Geuten K, Rahelivolona E, Wohlhauser S, Fischer E, Smets E, Küpfer P (2004) Phylogeny and biogeography of Balsaminaceae inferred from ITS sequence data. Taxon 53:391-403. https://doi. org/10.2307/4135617

Zhang H-W, Lu Y-F, Xu Y-L, Jin X-F (2017) New materials of the seed plants in Zhejiang (V). J Hangzhou Univ (Nat Sci Ed) 16:32-35. https://doi. org/10.3969/j.issn.1674-232X.2017.01.010

Zeng L, Yan R-Y, Zhang M, Xu W-B, Zhang L-J, Yu S-X (2016) Taxonomic significance of the pollen morphology of subg. Clavicarpa (Impatiens, Balsaminaceae). Guihaia 36:1245-1252. https://doi.org/10.11931/guiha ia.gxzw201507037

\section{Publisher's Note}

Springer Nature remains neutral with regard to jurisdictional claims in published maps and institutional affiliations.

\section{Submit your manuscript to a SpringerOpen ${ }^{\circ}$ journal and benefit from:}

- Convenient online submission

- Rigorous peer review

- Open access: articles freely available online

- High visibility within the field

- Retaining the copyright to your article

Submit your next manuscript at $\boldsymbol{\nabla}$ springeropen.com 